\title{
The Diegesis of Benjamin Button: A Method for Comparing Literature and Film ${ }^{1}$
}

\section{(La diégesis de Benjamin Button: método para comparar literatura y cine)}

\author{
Joe Montenegro Bonilla ${ }^{2}$ \\ Universidad Nacional de Costa Rica, Sede Regional Brunca \\ Universidad de Costa Rica, Recinto de Golfito
}

\begin{abstract}
This article proposes a specific structuralist methodology that may help organize the analysis of the relationship between literature and cinema. Through the instance of F. Scott Fitzgerald's short story "The Curious Case of Benjamin Button" and David Fincher's film adaptation of it, a focus on the comparable diegetic structures of a narrative cinematic text and the literary work on which it is based is offered, along with an exploration of the semiotic codes that support their comparative textual analyses.

\section{resumen}

Este artículo propone una metodología estructuralista específica que posibilita organizar el estudio para analizar la relación entre la literatura y el cine. Utilizando como ejemplo el cuento de F. Scott Fitzgerald "El curioso caso de Benjamin Button" y su adaptación al cine de David Fincher, se ofrece un enfoque en las estructuras diegéticas comparables entre un texto cinematográfico narrativo y la obra literaria en la cual se basa; además de una exploración de los códigos semióticos que sustentan los análisis textuales comparados de ambos textos.
\end{abstract}

1 Recibido: 2 de noviembre de 2012; aceptado: 7 de abril de 2013.

2 Correo electrónico: montenegrojoe@ hotmail.com

$$
L_{\text {etras }} 53 \text { (2013), ISSN 1409-424X; EISSN 2215-4094 }
$$


Key words: diegesis, structuralism, semiotic code, literature, film, adaptation Palabras clave: diégesis, estructuralismo, código semiótico, literatura, cine, adaptación

The relationship between literature and the arts has fascinated comparatists for over a century. However, the question of how such a connection may be faithfully described has occupied literary scholars ever since when, back in 1942, Professor René Wellek wondered whether all arts should not just be reduced to "branches of semiology." ${ }^{3}$ An heir to this query, the comparative analysis of literature and film seems to have embraced the semiotic solution quite comfortably, and in an age in which literary structuralism has been deemed by some old-fashioned and even naïve, it continues, however, to draw attention to how common systems and structures of meaning provide us with significant tools to understand the relationship between literature and the arts. Although there are many other, more discourse-oriented methods to approach the cinematic adaptation of literary texts, semiotics maintains its privileged status.

It follows, then, that certain basic Barthean concepts like those of semiotic "code" and "binary operation" serve as helpful organizers of the textual analysis of literary and cinematic texts. ${ }^{4}$ However, the classic notion of diegesis, as explained by Gerald Prince and employed by Robert Scholes, provides a particularly functional methodology for the study of the relationship between literature and film. Thereby, it is argued that the study of filmic adaptation both presupposes and demands a comparison of the diegetic structures that underlie the narrative texts involved, and that the existence of a diegetic logic between the two texts does not only justify the comparative textual analysis of both semiotic systems but also paves the ground for an understanding of their relationship.

3 René Wellek, "The Parallelism Between Literature and the Arts," Literary Criticism: Idea and Act. (Berkeley: University of California Press, 1974) 65.

4 Charles Bressler, Literary Criticism: An Introduction to Theory and Practice (New York: Prentice Hall, 1999) 97. 
Theorists and critics from Barthes to Culler have stressed the value of structuralism in literary criticism, and many others like Christian Metz and Peter Wollen have done the same for the discipline of film studies. ${ }^{5}$ Nevertheless, few semioticians - Scholes ${ }^{6}$ is one of them-have presented the comparatist of literature and cinema with specific instances of critical methodologies. Perhaps "the difficulties in extending literary models to film" that Raymond Bellour complains about have thwarted significant initiatives $;{ }^{7}$ however, one would expect that the potential for comparative criticism across the arts that structuralism offers would allow for more substantial proposals to emerge and for such proposals to overcome any system-specific barriers. Unfortunately, as a matter of course, not many of those who engage in comparative studies seem even willing to cross the boundaries between art forms, although, as Professor Mary Gaither puts it, "[this] area of investigation offers countless subjects, limited indeed only by man's knowledge and time itself." "Structuralism alone provides a wide range of possibilities for analysis, especially of the relationship between film and literature, which is ultimately a semioticone.

In his contemplation of the notion of adaptation, Dudley Andrew does contribute to the comparative studies of literature and cinema by suggesting the existence of a "global signified of the original [that is] separable from its text... [and so] can be approximated by other sign clusters." In other words, to the question of how the cinematic adaptation of a literary text is possible and approachable for criticism, Andrew answers with semiotics. "Adaptation is the most common

5 Gilbert Harman, "Semiotics and the Cinema: Metz and Wollen," Film Theory and Criticism (New York: Oxford University Press, 1999) 90-98.

6 Robert Scholes, Semiotics and Interpretation (New Haven, CT: Yale University Press, 1982) 57-72.

7 Robert Stam, Film Theory: An Introduction (Malden, MA: Blackwell, 2001) 187.

8 Mary Gaither, "Literature and the Arts," Comparative Literature: Method and Perspective (Carbondale, IL: Southern Illinois University Press, 1961) 154.

9 Dudley Andrew, "From Concepts in Film Theory," Film Theory and Criticism: Introductory Readings (New York: Oxford University Press, 1999) 456. 
practice in the exchange between literature and film;"10 therefore, it is only natural that a comparative approach should focus on such practice, which Andrew further explains as "a matter of searching two systems of communication for elements of equivalent position in the systems capable of eliciting a signified at a given level of pertinence."11 Ultimately, literature and film share commensurable semiotic codes, which account for the profoundness of their relationship. According to Metz, "What makes possible... the study of the relation between two separate sign systems, like [literature] and film, is the fact that the same codes may reappear in more than one system." ${ }^{12}$ A simple structuralist glance at one adaptation instance - that made by David Fincher of F. Scott's Fitzgerald Jazz Age tale "The Curious Case of Benjamin Button"-will hopefully reveal this truth.

Once the claim of semiotics as the most appropriate critical tool for the comparison of literature and film has been justified, only one more theoretical specification remains to be made. Within the world of structuralism, numerous conceptions and views might perfectly lend themselves to the analysis attempted here, yet none shall prove as suitable and as conducive as the narratological notion of diegesis mentioned above. Prince defines it as "the (fictional) world in which the situations and events narrated occur," ${ }^{13}$ but in discussing the connections between the novel and the film, Keith Cohen introduces a rather valuable explication of the idea:

Narrativity is the most solid media link between novel and cinema, the most pervasive tendency of both verbal and visual languages. In both novel and cinema, groups of signs, be they literary or visual signs, are apprehended consecutively through time; and this consecutiveness gives rise to an unfolding structure, the diegetic whole

10 Timothy Corrigan, Film and Literature: An Introduction and Reader (Upper Saddle River, NJ: Prentice Hall, 1999) 20.

11 Andrew, 457.

12 Qtd. in Andrew, 457.

13 Gerald Prince, Dictionary of Narratology (Lincoln: University of Nebraska Press, 2003) 20. 
that is never fully present in any one group yet always implied in each such group. [original emphases] ${ }^{14}$

The actuality of Cohen's words serves as groundwork and the organizing principle for the critical propositions hereby advanced. Furthermore, the use that Scholes makes of the term also helps shape and structure the arguments that support this comparative interpretation of the two "Benjamin Button" texts.

Although the average reader and movie-goer will not trouble themselves with musing about the notion of diegesis and its implications for their textual and artistic experiences, they are necessarily bound to submit themselves to its reality. "In reading [and watching] fiction...," Scholes explains, "we actually translate from the text to a diegesis." 15 It seems simply inevitable that a reader or viewer creates in his/her own mind a diegetic reality that more or less corresponds to the textual signs that he/she is being exposed to. The words and sentences - even the punctuation marks and spaces-for the fiction reader and the moving images and sounds for the film viewer are reconstructed in their minds to construct a diegetic logic that will help them interpret the meaning of a given text.

In fact, this same principle holds true when it comes to critically comparing two different narrative texts, one literary and the other cinematic. Scholes clears a path for structuralists to follow in order to carry out diegetic analyses of narrative texts:

The semiotician takes the reader's diegetic impulse and establishes a principle of structuration. The logic of diegetic structure provides a norm, a benchmark for the study of textual strategies, enabling us to explore the dialogue between the text and diegesis, looking for points of stress, where the text changes its ways in order to control the diegetic material for its own ends. ${ }^{16}$

14 Qtd. in Andrew, 457.

15 Scholes, 113.

16 Scholes, 114. 
Even though he is not providing a specific critical technique for comparatists, his description of how the contemplation of diegesis may aid the analysis of short stories and novels certainly suggests a possibility for exploring the common nature as well as the divergences between literature and film in their narrative forms. When Scholes refers to "structuration" and "textual strategies," it is impossible not to think of how precisely these two notions may help compare any two narrative forms, for it is in their particular structures that their potential for comparison lies. In the specific case of a cinematic adaptation of a literary text, what follows is that, given the dissimilar textualities of both texts, a common - or at least relatable-diegetic structure underlies them, the "benchmark" to which Scholes makes reference. It is proposed, then, that a true dialogue between the literary and the cinematic text is most naturally and successfully achieved through a comparison of their diegeses.

The diegetic contrast between Fitzgerald's story "The Curious Case of Benjamin Button" and Fincher's film version of it is evident. What in the former is nineteenth-century Baltimore in the latter is twentieth-century New Orleans; when in the story the protagonist is deeply misjudged and unfairly treated, in the film he grows to be praised and admired. These are only a couple of examples of the many divergences that separate the two narrated worlds from one another. However, one thing remains the same: the old becomes young, and this simple fact accounts for the fundamental diegetic logic of the "Benjamin Button" phenomenon.

The conditions of Benjamin's birth in both cases are marked by one particular reality that simply cannot be denied: he is born old. "There sat an old man apparently about seventy years of age," writes Fitzgerald as he describes his protagonist's birth (ch. 1). ${ }^{17} \mathrm{In}$ Fincher's film, the baby's condition may not be so apparent when

17 F. Scott Fitzgerald, "The Curious Case of Benjamin Button," <http://xroads.virginia.edu/ hyper/ fitzgerald/jazz/ benjamin/benjamin1.htm >, accessed 27 Feb. 2012. This is an unpaged document; chapter numbers will be used as reference in the text hereafter. 
the first shot of him is offered. No doubt, something is definitely wrong with the little creature, yet it is Dr. Rose's opinion that confirms the truth somewhat later. He explains bemusedly, "[the baby] shows all the deterioration, the infirmities, not of a newborn, but of a man well in his eighties on the way to the grave." ${ }^{18}$ The difference with which such a fundamental detail of the diegetic structure is presented in each case accounts for the distinctive semiotic nature of both art forms, but at the same time, also endorses the value of corresponding signs for a comparative analysis. Another diegetic element for which this is true is the character of Benjamin's father. In the original story, Mr. Button meets his "septuagenarian" baby at the hospital and then reluctantly goes shopping for some suitable clothes to dress him with (chs. 1-2). Fitzgerald offers a rather caricaturesque description of this event, in which the father evidently struggles to accept the fact that his newborn child is, to say the least, not what he expected. Fincher also works around this same theme of denial but in a much more pathetic way. He imbues the character of Mr. Button with other demons like grief and despair, out of which he abandons the infant at the stairs of an old people's home-quite a pun. In both cases, there is a message of denial and rejection, and although the codes and channels employed differ widely, the discursive weight of both representations supports the common diegetic structure.

Furthermore, Benjamin's struggle to be admitted as part of his world carries on to his childhood. The issue of expectation motivates his whole existence, and both Fitzgerald and Fincher build their diegeses upon it at this point. Fitzgerald's Mr. Button considers Benjamin's condition a mere sign of "stubbornness," and as if the poor boy could help it, his father requires him to play with a rattle, start collecting marbles, or even break things around the house, all proper puerile behaviors (ch. 3). "Thereafter," the narrator reveals, "Benjamin contrived to break something every day, but he did these things only because they were expected

18 David Fincher (Dir.), The Curious Case of Benjamin Button. Warner Bros. Pictures, 2008. Further references to the film will be indicated in the text. 
of him" (ch. 3). In the case of Fincher's Benjamin, not his father but his adoptive mother, Queenie, carefully defines his role, and not that of a child necessarily but of the old man that he seems to be. She reprimands him for making a spoon clank on the table so that he can hear it through his ear trumpet, and although she calls him "child," she forcefully pulls his wheelchair back in from the edge of the porch when he dangerously strives to look at some of his peers playing on the sidewalk. Whether for his childlike or for his inappropriately mature behavior, it seems that Benjamin Button always struggles to fulfill other people's expectations. This is certainly a key discursive and dialogic component that establishes a strong diegetic connection between the literary and the cinematic text, regardless of their differing semiotic structures.

As both narrations unfold, more of the diegetic connections that have made this filmic adaptation possible are revealed. However, Fincher manipulates Fitzgerald's original text for the purpose of suggesting a diegesis of his own, and in the process he has also, at least partially, reconstructed the text's discourse. For instance, the variations that Benjamin's love story undergoes from one text to the other not only complicate the diegetic structure but also underscore the textual differences and discursive particularities of both texts. In Fitzgerald's story, young beautiful Hildegarde Moncrief falls in love with him mainly on account of his mature demeanor. "I like men of your age," she declares, "...twenty-five is too wordly-wise; thirty is apt to be pale from overwork; forty is the age of long stories that take a whole cigar to tell; sixty is - oh, sixty is too near seventy; but fifty is the mellow age. I love fifty" (ch. 5). Hildegarde's initial, almost childish superficiality is contrasted by her later descent into disgrace due to her aging. She becomes "too settled in her ways, too placid, too content, too anaemic in her excitements, and too sober in her taste" (ch. 7). Such attitudes displease Benjamin so much that, in spite of his wife's absurd pleading with him to "stop it" (ch. 8) - meaning his growing younger every day-, he simply cannot help disliking her and growing apart from her, so the love story comes to an end. 
While Fitzgerald takes a surprisingly realistic stand by having his characters fall out of love with one another over time, Fincher exploits the Romantic possibilities of this diegetic component and uses it to his advantage. First, he changes the name of Hildegarde to Daisy, which immediately increases sympathy towards the character. Also, he has the two lovers meet in their childhood and maintain an offand-on platonic relationship over the course of the years until they finally reunite and start a family together. During this time, however, Benjamin continues to grow younger, and his concern over the burden that his condition will impose on his family forces him to leave them indefinitely. Up to this point, it is evident that Fincher has manipulated the diegetic structure of the text by placing the love story subplot at the center of it. Nevertheless, the topic of aging continues to govern the narrated world, although it incorporates new discursive undertones. Contrary to Benjamin's reactions to his wife's natural transformations in Fitzgerald's story, Fincher's Benjamin overcomes physical appearances and celebrates his beloved's aging body. When, after years of separation, Daisy visits him in a dim hotel room, she declares softly, "Nothing lasts." Benjamin then pulls her closer to him as she nervously claims, "Oh, Benjamin! I'm an old woman." A few moments later, a new sequence reveals Benjamin's gaze as he lovingly looks at Daisy getting dressed. Her imperfections are apparent, yet her lover's admiration for her is unquestionable. In any event, in both the story and the film, various textual strategies are used to construct relatable diegeses, the love story being only one example of them. Such is the actual source of comparative potential in this case.

Another section of the story that is constructed differently in each text corresponds to Benjamin's involvement in the war. The narrative codes used by Fitzgerald to relate these events tend to be quite straightforward and leave little room for confusion. Nevertheless, the emphasis on Benjamin's de-aging process is also manifest, and accentuates the discourse. In his youth, Benjamin had successfully fought in the Spanish-American war (ch. 7), yet his second attempt 
to join the army is doomed to fail. "Sixteen was the minimum age," explains the narrator, "and he did not look that old. His true age, which was fifty-seven, would have disqualified him, anyway" (ch. 10). However, this doesn't stop Benjamin from getting a uniform and demanding his right place in the army. His initial attitude is expected of a man of his position: a decorated officer. Upon his arrival at Camp Mosby, South Carolina, he shouts and orders a sentry and even a colonel around, all to the amusement of both men. However, his truth vanishes into illusion when his son Roscoe arrives; he ends up bringing with him a "weeping general, sans uniform, back... home" (ch. 10). This last detail clearly feeds the paradox of growing old versus de-aging that Fitzgerald has tried to delineate since the beginning of his story, and it also supports the discursive proposal that is constructed throughout the diegesis of the text.

In the case of Fincher's film, on the other hand, Benjamin's role in the war is less related to the central issue of his supernatural aging process than to the alternate topic of his spiritual journey in life. His involvement is rather accidental, as a cook for the Chelsey, the tugboat on which he has been working and sailing for several years and that is drafted by the U.S. Navy after Pearl Harbor. On board the Chelsey, Benjamin has grown from a tiny, old-looking boy into a strong-still white-haired-young man, especially thanks to Captain Mike Clark's mentoring. It is his relationship with this character, more than anything else, that impels Benjamin to go to war, even though he is, as Captain Clark himself says it, "a little moody for war," most probably on account of his unnoticed youth. But it is a new perspective on death what Benjamin truly gains from his war experience. "When it comes to the end," Captain Clark whispers as he fatally dies in the protagonist's arms, "you have to let go." A couple of shots later, a pensive Benjamin is seen contemplating a metaphorical sea of human helplessness in the face of death. "Out here," his narrating voice confesses, "death didn't seem natural." War has had an effect on Fincher's Benjamin that Fitzgerald's protagonist 
never fathoms, yet it seems that in both cases, similar diegetic materials serve as proposers of two particular discursive possibilities regarding warfare.

One last diegetic moment in "The Curious Case of Benjamin Button" seems worth discussing for the purpose of establishing an essential comparative connection with its filmic version. On account of the biographical style of both narrations, it is only natural to draw attention to the protagonist's old age and death just as it was given to his birth and childhood. Following the diegetic logic of his story, Fitzgerald describes an old Benjamin who has started to share his sphere with his own grandson. "The little grubby boy," says the narrator, "apparently about ten years of age who played around the house with lead soldiers and a miniature circus, was the new baby's own grandfather" (ch. 11). Fincher provides an analogous diegetic component early in his film. A long indoor shot shows an old woman helloing at the threshold while within the same frame a close-up of young Benjamin playing with his little soldiers is also offered. Here, like everywhere else in the film, Benjamin's behavior, regardless of his appearance, seems appropriate to his age. On the contrary, Fitzgerald's protagonist continues to struggle against his prospects as he "refus[es] to look sixty" (ch. 11). In the short story, Benjamin is born old, not only physically but psychologically as well, and as his body grows younger, so usually does his mind, hence his utter failure to fulfill the other characters' expectations. Nevertheless, his life comes to an end in much the same way in which any old man's life should end, "remember[ing] nothing" (ch. 11). Finally, in his loss of time and memory, he is both a newborn child and a dying old man, so all expectations are met.

Fincher's visual narration of these final episodes both resembles and challenges the original diegetic structure. Just as in the story Benjamin's nurse "[becomes] the centre of his tiny world" (ch. 11), so does a very old Daisy in the film. Aided by a sequence of exceptionally evocative shots, her own cracking voice narrates 
at this point: "The days passed, and I watched as he forgot how to walk... how to talk." Benjamin's body looks younger and younger with every image, but he is senile and suffers from dementia. However, where Fitzgerald's Benjamin perceives nothing but "the warm sweet aroma of the milk" (ch. 11), Fincher's experiences a last moment of lucidity. Towards the end, a memorable two-shot sequence shows the faces of old baby Benjamin and his beloved Daisy as she bemusedly stares back at him. "He looked at me," she says, "and I knew that he knew who I was, and then he closed his eyes as if to go to sleep." This is the moment of Benjamin Button's death, for as the shot opens wide and fades out to the scene of Daisy's own passing, she shrouds the baby's body.

The instances in which the diegetic structures of both Benjamin Button stories call for a comparative analysis are so numerous that only a glimpse of a few possibilities can be caught. Hopefully, this limited tour has provided such a glimpse and has served as ample evidence of the potential for criticism that the notion of diegesis offers to those who are interested in the study of film adaptations of narrative texts. In any event, however, there are two important foci of analysis in this case that will further support a structuralist scheme of diegetic recognition: the two key binary operations young/old and time/timelessness. In their own particular ways, both F. Scott Fitzgerald and David Fincher convey an alternative logic in which young is old and old is young and in which time is sometimes lost and sometimes recovered.

Early in Fitzgerald's story, the narrator establishes a paradoxical relationship between young and old when he refers to "the charming old custom of having babies" (ch. 1), which in turn prepares the setting for the fantastic event of the birth of the protagonist, Benjamin Button, "a baby of threescore and ten" [original emphasis] (ch. 1). Fitzgerald repeatedly emphasizes the infant's elderliness by providing descriptions like "dim, faded eyes" and "cracked and ancient voice" (ch. 1). They more or less harmonize with little Benjamin's 
adult ability to speak but at the same time contrast with his words: "I've only been born a few hours" (ch. 1). In the case of Fincher's film, a correlating youth/old age paradox is established by the fact that Mr. Button decides to leave his newborn child at the steps of an old people's home; however, this primordial binary operation has already been made evident, at least partially, in the opening scene. Actually, the very first shot of the film introduces viewers to a paragon of old age. The beeping of an ICU monitor is heard, and two seconds later a close-up of a very old pair of waking eyes is displayed. The camera pans out and reveals an elderly Daisy breathing gruntingly. Soon enough, her young daughter Caroline is introduced, and so the dual formula is completed. In both the story and the film, the old/young opposition is strategically presented, which accounts for a primitive discursive connection between the two texts.

Benjamin's life continues to convey a very particular sense of youth all throughout the story and the film as he grows younger instead of older with every chapter or sequence. Such initial emphasis suggests an affirmation of the value of the top factor over the bottom one in the young/old equation. In the story, first Mr. Button and later Benjamin himself seem to highlight youth insistently enough. The father, for example, had his son's hair "dyed to a sparse unnatural black" in order to achieve "his unwavering purpose" of crafting youth where there was none (ch. 3). On the other hand, Benjamin, after "years of normal ungrowth" (ch. 4) but existential failures, discovers that youth is something desirable and embraces it. The narrator describes this stage: "In addition, Benjamin discovered that he was becoming more and more attracted by the gay side of life. It was typical of his growing enthusiasm for pleasure that he was the first man in the city of Baltimore to own and run an automobile. Meeting him on the street, his contemporaries would stare enviously at the picture he made of health and vitality" (ch. 7). This new attitude towards life ends up costing him his marriage to Hildegarde Moncrief, for she, on the contrary, has naturally become old and unattractive. 
Fincher provides a diegetic equivalent to this change. After a failed attempt to resume his relationship with his beloved Daisy, Benjamin goes back home, the old people's home. Nevertheless, he is now younger than ever, as he is impersonated by a fresh, unblemished Brad Pitt. His daughter Caroline's voice continues to narrate his story. "Life wasn't all that complicated," she reads from her father's diary, "If you want, you might say I was looking for something." Here, Benjamin is talking about his newfound youth, and such energy takes the shape of a motorcycle, just as it was symbolized by the "automobile" of Fitzgerald's story. A short series of subsequent shots shows a young, attractive Benjamin Button wearing a leather jacket and riding his bike along a forest road. After a second rejection from Daisy a few years later, Benjamin once again embraces his youth by taking up sailing and women. "My Prayer" by the Ink Spots plays in the background as a very young, carefree Benjamin sails on his boat-much in the same James Dean fashion as before - and as he is seen in the company of several young ladies. As one such girl sneaks out of Benjamin's room, she surprisingly realizes where she has spent the night: her "camera" eyes pan across three room doors out of which very old faces peek. Once again, the youth/old age paradox is posed.

As Benjamin reaches the end of his life, the discursive model continues to center on the same young/old binary operation that allows for a diegetic comparison between the story and the film. However, there is now a reversal in the emphasis given to the two components of the formula. Old age is naturally stressed over youth but only at its expense, and Fitzgerald draws attention to such paradox in his work. Just like Mr. Button had forced his child to behave and look young, now Benjamin's own son Roscoe tries to age him. "Roscoe had approached him," says the narrator, "with the proposition that he should wear eye-glasses and imitation whiskers glued to his cheeks, and it had seemed for a moment that the farce of his early years was to be repeated" (ch. 10). Now in his advancing years, 
Benjamin realizes that his whole life has been trapped in a "curious and perverse" circle of unfulfilled expectations, much to the aversion of those who were supposed to love him unconditionally (ch. 11). Nevertheless, the eternal divorce between youth and old age seems to be at least partially reconciled at the end of Fitzgerald's story. The narrator anecdotally recalls the past of a very old man while at the same time describes the daily routine of an infant. In any event, however, both as a baby and as a senile man, Benjamin is fed on "nice soft mushy foods" (ch. 11), and his life ends like any old man's should: as peacefully as a baby sleeps.

In Fincher's cinematic version of the story, the ultimate representation of the young/old equation is realized by the juxtaposition of Benjamin's and Daisy's deaths. The viewer, as it was described above, is introduced to old Daisy's terminal condition early in the film, yet it is her actual death, following that of Benjamin, that positively calls attention to the paradoxical nature of this duality: she dies of old age, while the protagonist dies a baby. Although the unnatural age difference between Benjamin and Daisy is plainly depicted when the two characters first meet, in the final stages of their lives, such contrast is not only reversed but underscored. It is only logical, therefore, that in his senility an acne-ridden Benjamin returns to his rightful place, the old people's home where he grew up. "Benjamin is one of us," affirms Queenie's daughter, "If he needs a place to stay, it's all right; he can stay here." Soon after that, Daisy decides to move in too in order to take care of Benjamin and patiently await his death. She witnesses him descend into a sort of senescent infancy until he finally passes in her arms. The same "cracked ancient voice" that Fitzgerald gives to Benjamin in his childhood Fincher bestows upon Daisy as she narrates the end. That and the oldness of her face in the few shots left of the film perfectly oppose the sweet little baby that so peacefully goes to sleep. "Good night, Benjamin," she finally says just before she also goes to sleep eternally. 
Just as the young/old binary operation acts as a semiotic code for the comparative analysis of the diegetic structures of both texts, the paradoxical treatment of time also suggests a strong discursive connection between Fitzgerald's story and Fincher's film. In the story alone, numerous instances are given of the complex nature of time, "that eternal inertia which comes to live with each of us one day and stays with us to the end" (ch. 7). Time is sometimes timeless in "The Curious Case of Benjamin Button," and that view is supported by a constant search for ways to escape it. "As long ago as 1860," the narrator begins, "it was the proper thing to be born at home. At present, so I am told," he continues and thus ascertains his own timelessness (ch. 1). However, not only the narrator but also the characters show signs of living outside time. "Mr. and Mrs. Roger Button," for example, "were fifty years ahead of style" (ch. 1). Much has been said about the "perfect illusion" that Mr. Button tried to create to conceal the reality about his own son, yet he cannot prevent "the network of wrinkles on his face [from] becoming less pronounced" as he grows younger (ch. 3). Both these cases are examples of the time/timelessness opposition that governs the diegesis of the text.

Nevertheless, no other character in the story escapes the natural passage of time as utterly as its protagonist. With every year, "the blood flow[s] with new vigour through his veins" (ch. 7); instead of growing older like any normal human being bound by time, he grows younger. Such peculiar order of things, it must be said, does not always satisfy Benjamin himself, not to mention others. Sometimes he even wishes that "the grotesque phenomenon which ha[s] marked his birth would cease to function" (ch. 8). Paradoxically enough, Benjamin has escaped time yet not his own timeless reality. At the end of his life, nonetheless, he ultimately challenges the very order of past, present and future by doing what only a timeless being can do: forget. "There were no troublesome memories in his childish sleep," says the narrator, “...there were no dreams, no dreams to haunt him" (ch. 11). Such assertion invariably talks about 
a human need to escape time, to leave everything behind and start anew. Unfortunately, unlike in the case of Benjamin, who at the end "remembered nothing" (ch. 11), memory turns time into a jailhouse and timelessness into daydream for everyone else.

In the case of The Curious Case of Benjamin Button, the film, a very precise image embodies the time conundrum like none in the original story. The time/timelessness formula is symbolized here by the train station clock, which runs backwards, just like Benjamin's age. An enchanting series of vintage images is displayed as Daisy narrates the story of Monsieur Gateau, "the finest clockmaker in all of the South," who loses his son in the Great War. As a result of his grief, he decides to build a very special clock for the train station, one that runs backwards. "I made it that way," he explains, "so that perhaps the boys that we lost in the war might stand and come home again." Time is magically turned back as he speaks, for a terrible war sequence is played in reverse and ends with the clockmaker's son coming back to his parents. Just like Roscoe wishes his father did in the original story, time here "turn[s] right around and start[s] back the other way" (ch. 9). In fact, as the viewer learns later, Mr. Gateau's dream of escaping time by reversing it is realized in the character of Benjamin Button in the film, whose life starts at its end and runs backwards toward its beginning.

The metaphor of the clock is perfected in the final sequence of the movie, thus completing the time/timelessness circle that has been so central to the diegesis of both the film and the story. "In 2002," Daisy's old voice is heard narrating, "they put up a new clock in that train station." This is the first time after Mr. Gateau's story is told that the symbol is mentioned, and the image of a digital clock properly running forward high upon the station entrance is offered as illustration. Accordingly, the natural passage of time is finally restored, and with Benjamin's death, "in the spring of 2003," everything seems to go back to normal. However, the issue of time and the undying human desire to escape it is highlighted once more in the very last shot 
of the movie. Mr. Gateau's original clock, abandoned in a storage shed, is reached by the hurricane waters that flood the room. As the emergency alarms are heard blaring and the stream flows towards the partially covered clock, the shot closes up on the machine, only to reveal that it is still ticking, its second hand moving in reverse. Benjamin's life, it seems, has battled time and has won.

In conclusion, the question of whether or not structuralism is the best road to follow towards a true comprehension of the relationship between literature and the arts still remains. Nonetheless, one thing is true: semiotics does provide comparatists with a wide range of critical possibilities, although many of them are yet to be discovered. In the specific case of literature and cinema, the Saussurean legacy of decoding sign systems has facilitated an exploration of their correlative structures of meaning. It actually supports and feeds a continuous examination of the many ways in which both art forms relate to one another, not only in terms of their distinctive language systems and modes of expression but also in relation to discourse. After all, as Stam puts it, one purpose in approaching art products is "to discern the cultural and ideological codes operative in them." 19 Accordingly, semiotics provides the raw material for comparative critics to devise and put into practice new methods for the analysis of film and literature.

One such method is the study of the diegetic structures that organize and give meaning to a literary text and its cinematic adaptation, as in the case of F. Scott's Fitzgerald's short story "The Curious Case of Benjamin Button." This and the structural logic provided by the presence of commensurable semiotic codes and binary operations make it possible for the critic to elaborate intertwined explanations of how a narrative film interprets and rewrites the literary text from which it borrows its existence. Therefore, the relationship between narrative literary and cinematic texts in adaptation may

19Stam, 192. 
be successfully understood through a semiotic approach to textual analysis justified by the existence of a relatable diegetic logic. As part of the process that such affirmation necessarily implies, not only is meaning constructed by the reader/viewer, but his/her work as a comparative critic begins to lay the foundation for the practice of a new form of interpretive structuralism. 